\title{
Smoking prevalence in the European Union: a comparison of national and transnational prevalence survey methods and results
}

\author{
Ilze Bogdanovica, ${ }^{1}$ Fiona Godfrey, ${ }^{2}$ Ann McNeill, ${ }^{1}$ John Britton ${ }^{1}$
}

${ }^{1}$ UK Centre for Tobacco Control Studies, University of Nottingham, Division of Epidemiology and Public Health, Nottingham, UK

${ }^{2}$ International Union Against Tuberculosis and Lung Disease, Luxembourg

\section{Correspondence to} Ilze Bogdanovica, UK Centre for Tobacco Control Studies, University of Nottingham, Division of Epidemiology and Public Health, Clinical Sciences Building, City Hospital Nottingham NG5 1PB, UK; mcxib3@nottingham.ac.uk

Received 5 February 2010 Accepted 14 June 2010 Published Online First 21 October 2010

\section{ABSTRACT}

Objectives To determine whether the European Commission Eurobarometer survey of 27 European Union (EU) member states produces reliable smoking prevalence estimates when compared to national prevalence survey data, and to identify approaches to standardising the measurement of smoking prevalence in the EU.

Methods This was a direct comparison of questions, sampling methods and smoking prevalence estimates, between the 2006 Eurobarometer study and contemporaneous national surveys. All 27 EU member states were included. Participants were people surveyed in the 2006 Eurobarometer study and in various national surveys in the closest year to 2006 for which data were available. The main outcome measures were the mean and range of differences in prevalence estimates between the Eurobarometer and national surveys.

Results Most national surveys used similar multistage sampling methods and involved sample sizes of 3000 or more, but the phrasing of the questions used to define smoking, the inclusion or exclusion of occasional smokers, the age ranges of participants and the frequency of national surveys varied substantially between countries. The Eurobarometer study used the same questions in all countries but in sample sizes of 1000 , or in 3 countries, 500. Eurobarometer 2006 smoking prevalence estimates were on average 0.37 percentage points higher than those in national surveys, but with a $95 \%$ range from -10.49 to +11.23 percentage points. At the extremes, the equivalent national prevalence estimate for Slovakia was 13.0\% higher and for the UK $10.0 \%$ lower than the Eurobarometer figure.

Conclusions Measurements of the prevalence of smoking, the biggest avoidable public health threat in the European Union, are highly discrepant within countries between national and European Commission survey estimates. Monitoring national smoking prevalence on a regular basis, using standardised methods in representative population samples, is an urgent priority for the EU.

\section{INTRODUCTION}

Smoking has been prevalent in Europe since the early 20 th century, ${ }^{1}$ and for many years has been the largest avoidable cause of serious disability and mortality in the European Union (EU). ${ }^{2}$ An estimated $26 \%$ of people aged 15 years and older in the $\mathrm{EU}$, or about 100 million people, are current daily smokers $^{3}$ and about 50 million of these will die prematurely from smoking unless they quit. ${ }^{4}$ Given the scale of this problem, accurate measurement and monitoring of trends in smoking prevalence in EU countries should be a high priority. However, over the past 15 years the European Commission (EC) has measured smoking prevalence in all member states on only four occasions, in Eurobarometer surveys carried out in 2002, 2005, 2006 and 2008. ${ }^{3} 5-7$ The surveys use samples of about 1000 participants from most countries and the published reports contain no detailed breakdown by gender, age or other characteristics by country. Smoking prevalence is also measured in national surveys in member states, usually with larger samples and hence in more detail than the Eurobarometer, but with different questions and varying frequency.

Inspection of national and Eurobarometer prevalence estimates reveals some substantial discrepancies. For the UK, for example, smoking prevalence estimates from the large and nationally representative General Household Surveys in 2002, 2005 and 2006 were $26 \%, 24 \%$ and $22 \%$, while the Eurobarometer figures for the UK in the same years were respectively $45 \%, 29 \%$ and $32 \% .^{5-7}$ This suggests either that differences in the phrasing of questions used to define smoking, errors arising from sampling methods or sample sizes, or all of these factors, have a significant impact on estimates from national or Eurobarometer studies, or both.

Since these considerations question the validity of the Eurobarometer surveys as the main source of smoking prevalence data for the entire EU, we have summarised and compared the methods, sample sizes and prevalence estimates provided by the Eurobarometer survey and in available national studies. Since national data tend to be published rather later than Eurobarometer results and many countries do not have more recent data available, our primary comparison is between data from Eurobarometer 2006 and from national surveys closest in time to 2006.

\section{METHODS}

We used a range of internet search strategies to attempt to identify the most recent national survey of smoking prevalence, and a summary of the survey methods used, for each of the $27 \mathrm{EU}$ countries. Typically the sources of data were surveys addressing a range of topics but including some questions on smoking, and these sources usually provided details of sampling methods, sample size and phrasing of the questions used to define and measure smoking. In cases in which this methodological information was not provided or was unlocked scheme, see http:// tobaccocontrol.bmi.com/site/ about/unlocked.xhtml 
incomplete, we attempted to make email contact with individuals or organisations given on the websites as sources of further information, and if that proved unsuccessful, we used the European Health Interview and Health Examination Surveys Database $^{9}$ and the WHO Global InfoBase ${ }^{10}$ as secondary sources of information. From these sources we attempted to establish the age range and number of participants included, the response rate, and the sampling and data collection methods used for the survey. We also attempted to ascertain the phrasing of the questions to determine whether they included smokers of any tobacco product or cigarette smokers only, and whether they included and distinguished occasional and daily smokers.

We then compared the methods used and estimates obtained in these national surveys with those in the Eurobarometer 2006 survey. Where more than one recent national survey was available we took data from the year closest to 2006, or from 2005 if the choice was between 2005 and 2007. If more than one national survey was available in the closest year to 2006, we used data from the largest study. To describe the agreement between Eurobarometer and national prevalence estimates we calculated the mean and 95\% range of differences between them, and assessed the correlation between them. We are aware that more recent data have been or are being collected in several countries, but limited our analysis to data available at the time of writing in December 2009. Since the Eurobarometer 2006 study presented summary data only for the 25 countries in the $\mathrm{EU}$ before the accession of Bulgaria and Romania, we also calculated the mean Eurobarometer summary figure for all 27 EU countries adjusted for population in each country in the age group $15+$, as it had been done in the Eurobarometer study.

\section{RESULTS}

The national surveys we identified, phrasing of the questions used to describe current smoking (or a description of reported smoking status in cases where we were unable to obtain specific phrasing), the age range of participants, the sampling and survey methods used, the sample size and participation rates, the prevalence estimates reported and the equivalent information from the Eurobarometer 2006 survey for the 27 EU countries are summarised in table 1 . At the time of analysis the majority of recent national surveys had been carried out between 2003 and 2007, with only seven countries (Finland, Luxembourg, Malta, The Netherlands, Sweden, UK and Ireland) having data for 2008. For one country, Greece, we were unable to find recent data on smoking prevalence from a national survey and instead had to use a prevalence estimate from a published article that quoted a recent national survey as the source of the estimate. Data on the sample size and age group included were also given in this secondary source, but we were unable to ascertain any further information about the original survey. Data for the UK were obtained from the General Household Survey, which excludes Northern Ireland ( $3 \%$ of the UK's population ${ }^{61}$ ).

The majority of countries used multistage, representative population sampling methods, and most used personal face-toface interviews (sometimes with additional questionnaires for private completion) to collect data, though six used postal survey methods, one an online survey and two used telephone interviews. We were unable to establish the data collection procedure used in Greece. The number of participants in national surveys varied widely between countries, the lowest being Malta with 1369 individuals but most others including at least 3000 people. All surveys imposed a lower age limit on participants (typically 15 or 16 years, but ranging from 10 in
Portugal to 25 in Bulgaria and Greece); and some surveys an upper limit, usually 64 years. Available response rates varied from $55 \%$ in Latvia to $92 \%$ in Cyprus; we were unable to ascertain the response rates for five countries. The Eurobarometer survey included around 1000 people in each country, except in Cyprus, Luxembourg and Malta where approximately 500 people were surveyed, and in Germany, with 1551 participants. Sampling methods were similar to the national surveys, with a lower age limit of 15 years and no upper age limit. The response rate in the Eurobarometer study was not given in the published report.

The questions on smoking used in national surveys varied markedly in phrasing, but clearly ascertained daily and occasional (non-daily) smoking in 19 countries. For clarity therefore we have condensed the questions used in these countries into uniform text in table 1 , and for the other countries have summarised the approximate questions used. Surveys in Bulgaria, Slovakia, The Netherlands and Luxembourg reported daily and occasional smoking, but we were unable to establish the precise questions used. Germany reported regular and occasional, rather than daily or occasional smoking, but did not explicitly define regular smoking. For Greece the estimated prevalence is for all smoking, but the questions used are unknown. In Malta only daily cigarette smoking was measured; the Czech Republic measured all smoking but broke only cigarette smoking down into daily or occasional; and in the UK, the question asked about smoking cigarettes at all nowadays (cigar and pipe smoking were excluded, regular smoking of either being extremely rare). Questions used in Austria, Italy and Romania appeared to distinguish daily and occasional smoking, but prevalence was reported only for daily smoking for Austria, and all smoking for Italy and Romania. In some countries additional questions were asked about the number of cigarettes, cigars or pipes smoked by daily smokers and the frequency of smoking for occasional smokers.

The questions used in the 2006 Eurobarometer survey defined a smoker as one who smoked manufactured cigarettes, handrolled cigarettes, cigars or pipes, and asked these smokers if they smoked regularly or occasionally. Regular smoking was not defined in the report. Cigarette smokers were asked about daily consumption, and included a response category for those who did not smoke every day. Thus the Eurobarometer provides data on regular or occasional smoking of any product and daily or non-daily smoking of cigarettes. Since most national surveys also measured all smoking (of cigarettes, cigars and pipes) we used figures for all smoking to compare like with like estimates between national and Eurobarometer surveys for all countries except the UK and Malta, for which the Eurobarometer cigarette smoking prevalence figure was used. Since the Eurobarometer survey did not publish gender-specific estimates, we compared prevalence for both sexes combined. The estimates compared are displayed in figure 1

The highest smoking prevalences reported in national surveys were from Bulgaria (45.2\%), Greece (40\%) and Slovakia (38\%); and the highest Eurobarometer estimates for Greece (42\%), Bulgaria (36\%), and Latvia and Hungary (36\%). The lowest estimates in national surveys were for Portugal (19.7\%), UK $(22 \%)$ and Italy $(22.7 \%)$; and in Eurobarometer for Portugal $(24 \%)$, Slovenia (23\%) and Sweden (18\%). On average, the Eurobarometer prevalence estimates were higher than those from national surveys by 0.37 percentage points, but with a $95 \%$ range (on 26 degrees of freedom) from -10.49 to +11.23 percentage points. At the extremes of the range of absolute differences the national estimate for Slovakia was 13 percentage 


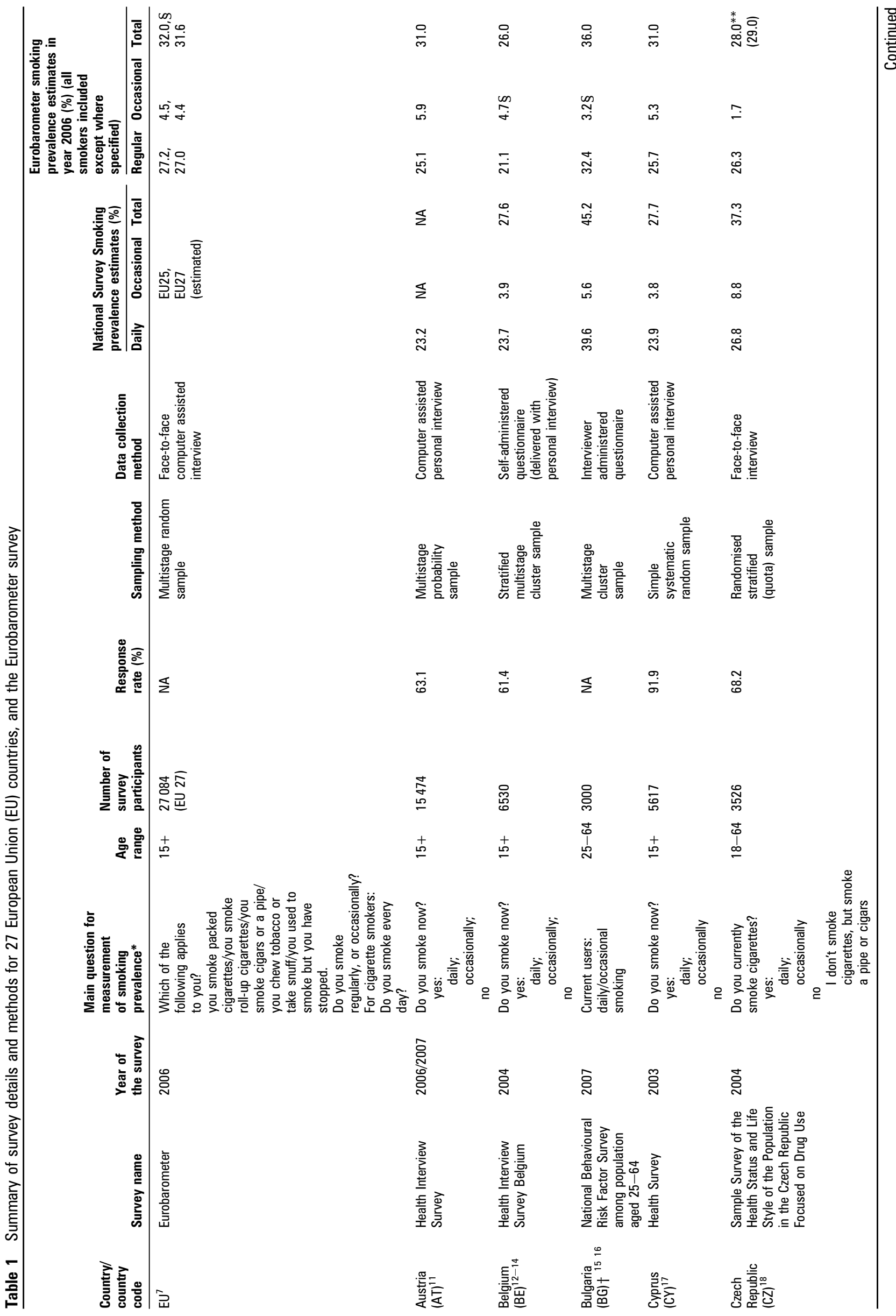




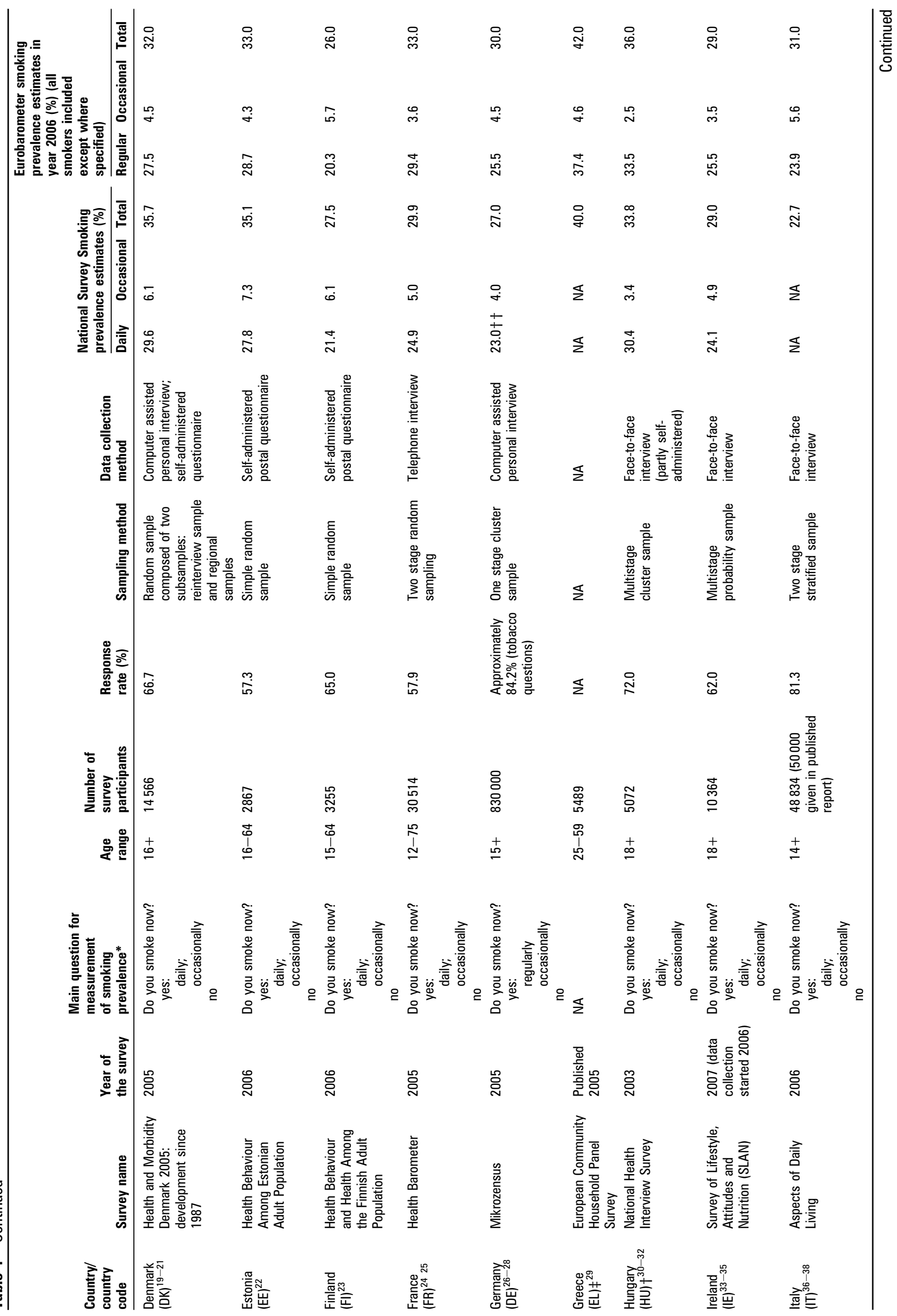



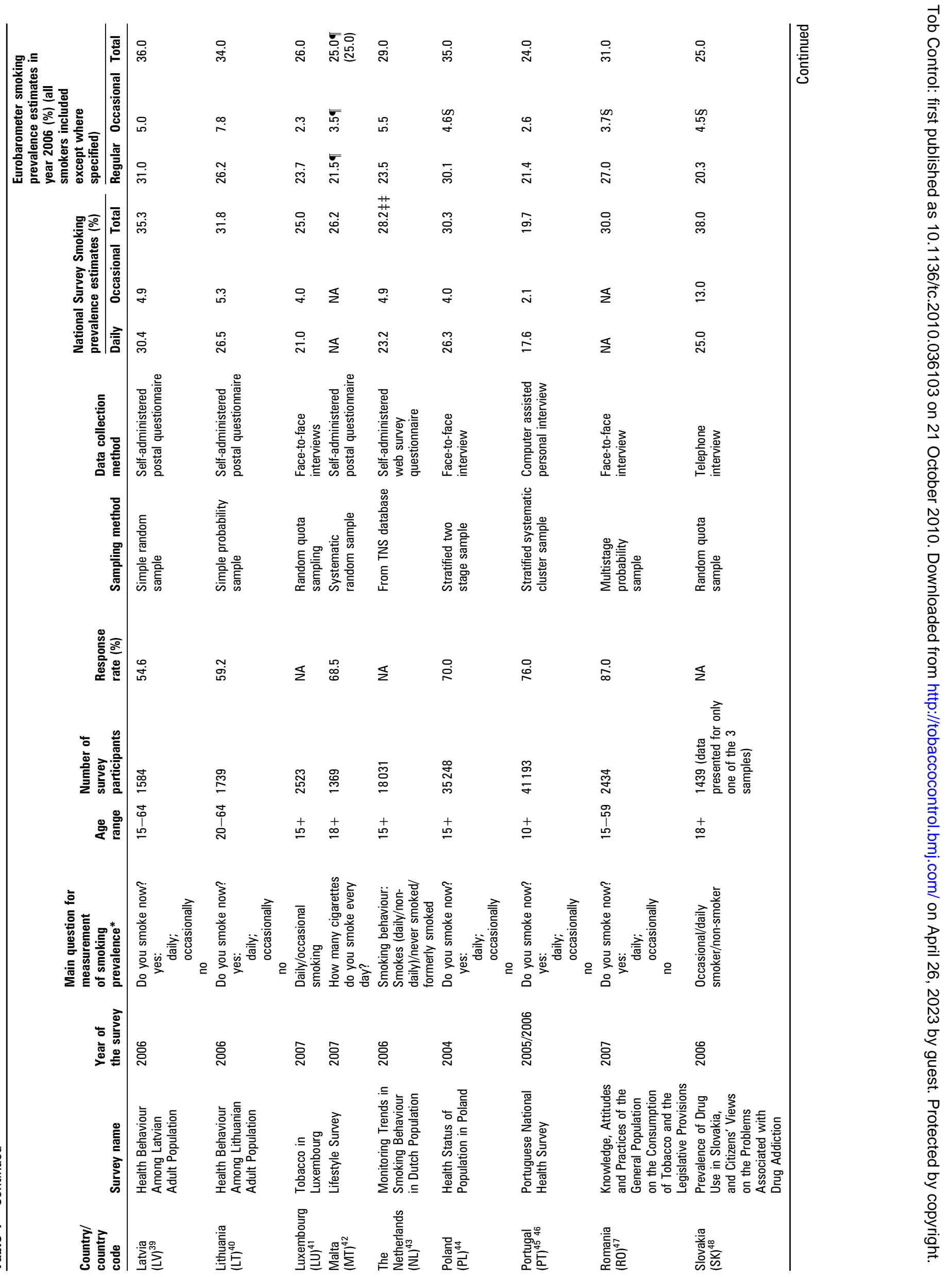


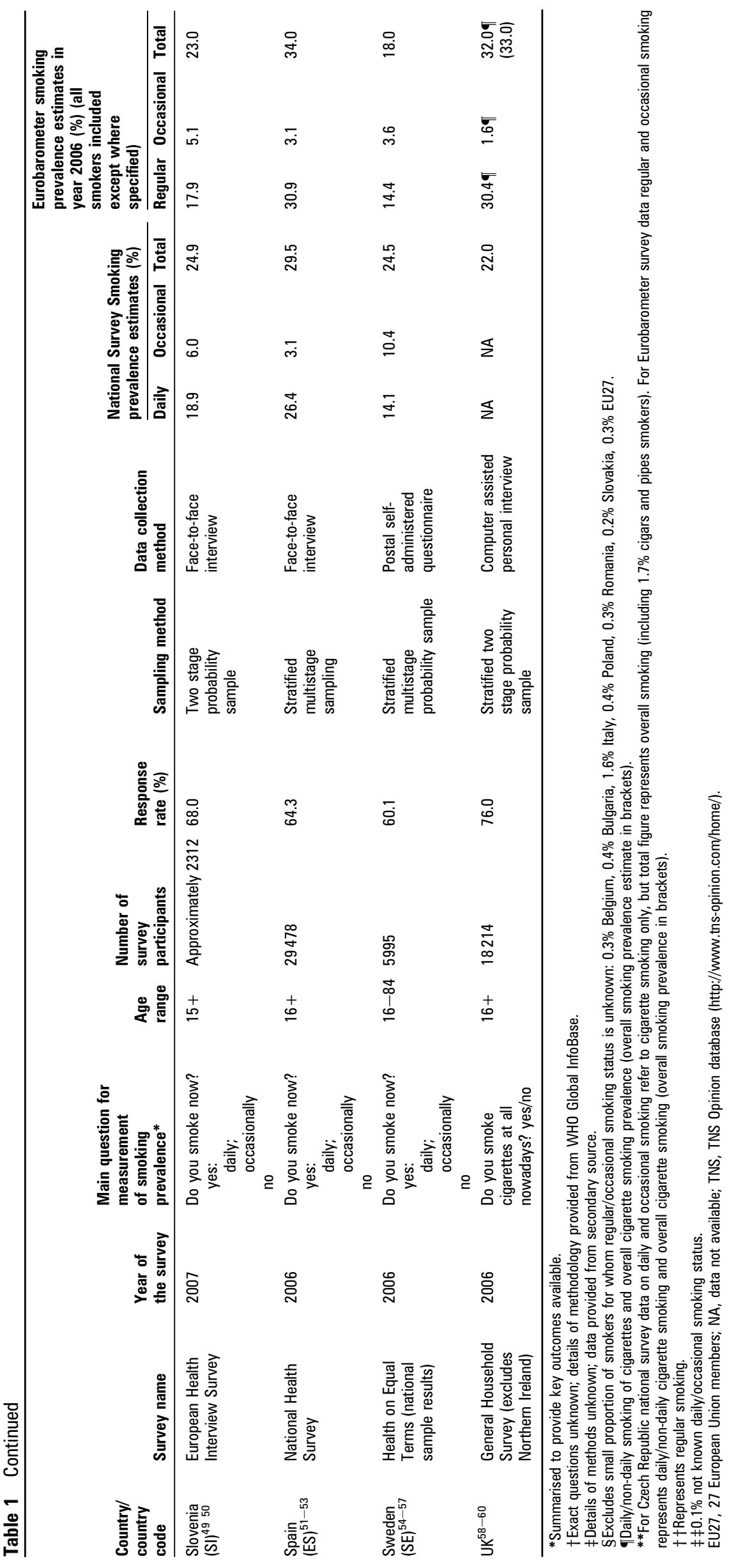




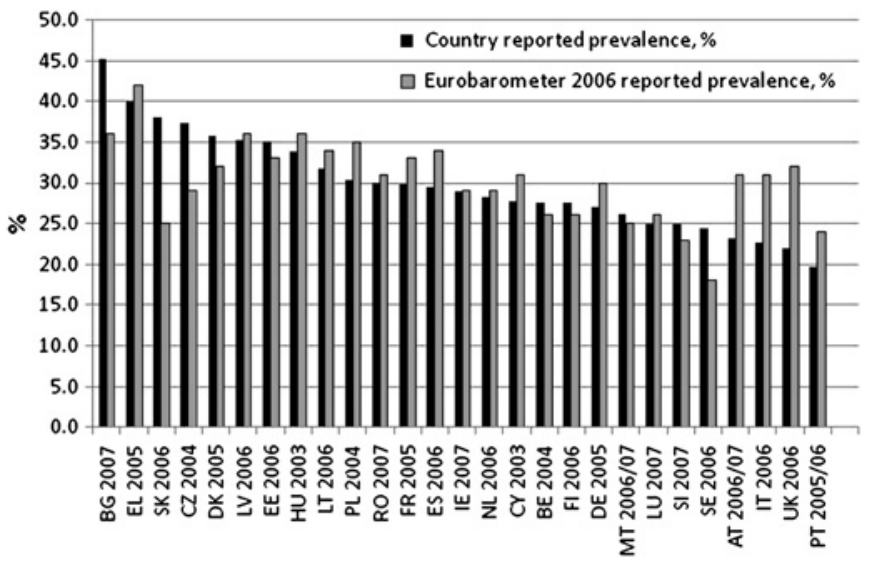

Figure 1 National and Eurobarometer 2006 smoking prevalence estimates for the European Union (EU) countries.

points higher than the Eurobarometer figure, while the UK national estimate was 10 percentage points lower. There was positive and significant correlation between Eurobarometer and national smoking prevalence estimates $(r=0.58 ; \mathrm{p}<0.01)$.

Mean daily and occasional smoking prevalences in the 20 countries for which daily and occasional smoking prevalence figures were available were $25.1 \%$ and $5.6 \%$, respectively, and for the same countries in the Eurobarometer study, mean regular and occasional smoking prevalence estimates were $25.5 \%$ and $4.2 \%$. Comparison of the national survey estimates with figures from the more recent (2008) Eurobarometer survey, which used similar methods to the 2006 study, reveals mean figures that were 1.5 percentage points higher in Eurobarometer, with a 95\% range from -6.7 to +9.6 percentage points.

\section{DISCUSSION}

In the EU in the year 2000, smoking caused over 650000 deaths and serious chronic disease in about 13 million people, ${ }^{62}$ and in 2002 passive exposure to cigarette smoke caused nearly 20000 deaths in non-smokers ${ }^{63}$ and had a substantial impact on the health of children. ${ }^{64}$ Monitoring the prevalence of smoking accurately, by age, sex and socioeconomic status, using standardised methods to enable between-country comparisons, is an essential prerequisite for implementing and assessing effective public health policy to prevent smoking and the diseases it causes. This study demonstrates that while relatively unbiased as a measure of total smoking prevalence across the EU, the main EU survey of smoking prevalence in member states generates estimates that are in some cases widely discrepant from more substantive national sources and does not provide age or gender-specific data by country. While in some countries the availability of high quality and frequently measured national data make the Eurobarometer unnecessary for monitoring purposes, in those countries in which reliable national data are obtained infrequently, and in some cases are difficult to locate, the Eurobarometer is an important source of information. Our study suggests that the data it provides are lacking in accuracy and detail at a national level.

Some of the discrepancy between national and Eurobarometer survey results will be due to methodological differences. Most surveys used broadly comparable multistage sampling methods to identify participants, but some national surveys did not publish a participation rate and many of those that did achieved participation in less than $70 \%$ of those sampled. Bias arising from relative nonresponse in particularly high or low smoking prevalence subgroups is therefore possible. The Eurobarometer survey did not publish response rates. Use of interviewer-administered, postal, internet or telephone-based survey methods is certainly likely to have influenced results, since the latter two in particular tend to exclude the relatively disadvantaged (and high smoking prevalence) sectors of the population in many countries. Differences in the phrasing of the questions used to ascertain smoking habits may also have contributed, though most countries used a consistent approach in measuring all smoking (including cigars and pipes) on a daily or occasional (non-daily) basis. Since about $5 \%$ of people describe themselves as occasional smokers, the distinction between regular and occasional needs to be clearly defined, and daily smoking is an obvious and simple distinction to draw. Exclusion of non-daily smoking from the overall prevalence figure, as for example in Austria, will lead to substantially lower prevalence estimates. Since the great majority of smokers in the EU are cigarette smokers, inclusion or exclusion of pipe and cigar smoking makes little difference to the figures, but nevertheless results in slightly higher overall prevalence estimates if included and should therefore be measured.

Since smoking rates vary markedly with age, ${ }^{6} 85$ differences in the age range surveyed are also potentially important. Smoking in the very young and the very old tends to be relatively uncommon, so inclusion of individuals in these age ranges will tend to reduce prevalence estimates. Many countries set no upper age limit on participation but many excluded those aged over 64, and in two cases, those over 59. At the lower age limit, most countries included those aged 15 and over, but Bulgaria and Greece excluded people aged under 25. Since smoking is typically common in young adults in the 20-24-year-old age group, this may have resulted in an underestimate of total prevalence in these two countries.

Sample sizes were all higher, and in most cases substantially higher, in national than in the Eurobarometer surveys. With unbiased sampling and participation, the lower sample sizes in the Eurobarometer study should not result in systematic error in the overall prevalence estimates, but will increase random error and precludes detailed breakdown of smoking by gender, age, or socioeconomic status within countries. It is possible that differences in the probability sampling methods used and the weighting of responses in the analysis of survey results impacted on these differences between national and Eurobarometer estimates, but few studies provided details of these procedures and we were therefore unable to explore these effects any further. It has also been argued that measures of self-reported smoking prevalence tend to underestimate true tobacco smoking rates, and that use of biological markers would provide more accurate information about person's exposure to tobacco smoke. ${ }^{65}$ However, none of the studies we analysed included any objective verification of smoking status. Differences in timing of the national and Eurobarometer studies may also have contributed to prevalence differences, though we found no evidence of systematic bias in this respect (data not shown). Unfortunately, given the relatively small numbers of prevalence estimates available to us, we were unable to estimate the independent effect of these various factors in our analysis.

In 2008 a further Eurobarometer study was carried out, and the mean of the differences from national estimates, and their range were broadly similar to the 2006 study. Further evidence of the inaccuracy of individual country estimates are evident in the Eurobarometer figures for the UK, which since 2002 have varied between $28 \%$ and $45 \%,{ }^{3}{ }^{5-7}$ while national figures have fallen from $26 \%$ to $21 \%{ }^{8}$ UK national survey data indicate that only about $1 \%$ of the population smokes cigars and pipes, ${ }^{8}$ so the discrepancy between these figures is not due to inclusion of other types of tobacco in the Eurobarometer estimates. 
Overall our study indicates that the measurement and monitoring of trends in smoking prevalence in EU countries at national and EU levels is inconsistent, unstandardised and in many cases infrequent. Harmonisation of methodology, or at least the inclusion of a basic set of common questions, would therefore be a major step towards the generation of data suitable to compare smoking prevalence in European countries over place and time. While it may not be possible to use identical sampling methods in all countries, the approaches used in national surveys should be broadly consistent, using standardised age ranges, and data on participation rates are needed to determine how representative the participants are of the target population. At present, the Eurobarometer survey provides a standardised approach but with inadequate sample sizes, while national surveys tend to provide reasonable sample sizes but relatively little common ground in terms of smoking definitions. Less than half of all EU countries measure smoking prevalence on an annual or biennial basis.

A standardised approach to measuring smoking prevalence would use similar questions in all countries and, to allow for differences in the types of tobacco smoked, ask about smoking of all tobacco products. Since most countries currently use daily smoking as a definition of regular as opposed to occasional smoking, we would suggest that all countries should be encouraged to adopt questions that ascertain daily and occasional smoking of any tobacco products, and of manufactured or hand-rolled cigarettes. This would allow direct comparison of prevalence between national surveys, at least within the minimum common age range. Ideally the surveys should include all aged 15 and over. Sample sizes need to be adequate to detect differences in prevalence between sexes, age and socioeconomic groups, so that trends in uptake and cessation can be identified within them; in practice, this will probably require samples of the order of 3000 people. Probability sampling methods and weighting also need to be harmonised as closely as possible, in case these also contribute to bias between national and transnational estimates. National surveys should ideally be repeated at least every 2 years to allow adequately monitor changes in smoking prevalence over time, though a case could be made for much more frequent monitoring.

All of these recommendations also apply to the Eurobarometer study, which, in the absence of reliable or frequent data from some countries, is the only available indicator of smoking prevalence and prevalence trends in some areas of

\section{What this paper adds}

- The prevalence of smoking in the 27 European Union member states is measured infrequently in most countries and the methods used differ substantially between countries.

- The European Commission Eurobarometer survey uses standardised methods to measure prevalence in all member states, but does so using relatively small sample sizes and at irregular intervals.

- Average Eurobarometer prevalence estimates are slightly higher than the average of national estimates, but the range of differences is very wide and includes some major discrepancies.

- This paper highlights the need for standardisation of the methods used to measure the prevalence of smoking in time and place across Europe.
Europe. Since monitoring smoking is such a health priority it is important that the Eurobarometer continues to provide directly comparable data broken down at least by age and gender, using a core set of questions to provide comparable responses to most national studies and on a regular basis. For the time being however, measurement of smoking prevalence in Europe is inadequate in many respects, and needs to be reformed.

Funding This study was originally supported by funding from the European Respiratory Society Tobacco Control Committee and latterly by the UK Centre for Tobacco Contro Studies, with core funding from the British Heart Foundation, Cancer Research UK, Economic and Social Research Council, Medical Research Council and the Department of Health under the auspices of the UK Clinical Research Collaboration.

\section{Competing interests None.}

Provenance and peer review Not commissioned; externally peer reviewed.

\section{REFERENCES}

1. Doll R. Tobacco: a medical history. J Urban Health 1999;76:289-313.

2. European Commission Health and Consumer Protection Directorate General. http://ec.europa.eu/health/ph_determinants/life_style/Tobacco/tobacco_en.htm (accessed 19 Nov 2009)

3. Flash Eurobarometer No 253 Survey on Tobacco. Analytical report. Hungary: The Gallup Organisation, 2009. http://ec.europa.eu/public_opinion/flash/fl_253_en.pdf (accessed 18 Nov 2009).

4. Doll R, Peto R, Boreham J, et al. Mortality in relation to smoking: 50 years observations on male British doctors. BMJ 2004;328:1519.

5. Special Eurobarometer 183/ Wave 58.2 smoking and the environment: actions and Attitudes. Brussels: European Opinion Research Group EEIG, 2003. http://ec.europa. eu/health/ph_determinants/life_style/Tobacco/Documents/eb582_smoking_env_en. pdf (accessed 18 Nov 2009).

6. Special Eurobarometer 239/ Waves 64.1 Attitudes of Europeans towards tobacco. 2006. TNS Opinion \& Social. http://ec.europa.eu/public opinion/archives/ebs/ ebs 239 en.pdf (accessed 18 Nov 2009).

7. Special Eurobarometer 272c/ Wave 66.2 Attitudes of Europeans towards Tobacco. Report. 2007. TNS Opinion \& Social. http://ec.europa.eu/health/ph_determinants/ life style/Tobacco/Documents/ebs272c en.pdf (accessed 18 Nov 2009).

8. Robinson S, Lader D. General Household Survey 2007-Smoking and drinking among adults, 2007. Newport: Office for National Statistics. http://www.statistics. gov.uk/downloads/theme_compendia/GHS07/GHSSmokingandDrinkingAmong Adults2007.pdf (accessē 19 Nov 2009).

9. European Health Interview \& Health Examination Surveys Database. Scientific Institute of Public Health (IPH) Brussels, National Institute of Public Health. European Commission. https://hishes.iph.fgov.be/index.php?hishes=home laccessed 10 Dec 2009).

10. WHO. The WHO Global InfoBase. World Health Organization (WHO). https://apps. who.int/infobase/report.aspx (accessed 10 Dec 2009).

11. Health Interview Survey 2006/2007. Wien: Statistics Austria, 2007. http://www. statistik.at/web_de/dynamic/statistiken/gesundheit/publdetail?id=4\&listid=4\& detail=457 (accessed 08 0ct 2009).

12. Bayingana K, Demarest S, Gisle L, et al. Health Interview Survey Belgium 2004 I Introduction (Enquête de Santé par Interview Belgique 2004 Livre I Introduction). Bruxelles: Institut Scientifique de la Santé Publique, 2006. http://www.iph.fgov.be/ epidemio/epifr/crospfr/hisfr/his04fr/his11fr.pdf (accessed 03 Nov 2009).

13. Bayingana K, Demarest S, Gisle L, et al. Health Interview Survey Belgium 2004 III Lifestyle (Enquête de Santé par Interview Belgique 2004 Livre III Style de Vie). Bruxelles: Institut Scientifique de la Santé Publique, 2006. http://www.iph.fgov.be/ epidemio/epifr/crospfr/hisfr/his04fr/his35fr.pdf (accessed 08 0ct 2009).

14. Health Interview Survey 2004 Belgium research protocol. Brussels, 2005. http:// www.iph.fgov.be/epidemio/epien/crospen/hisen/his04en/protocol2004.pdf (accessed 24 Nov 2009).

15. World Health Organization Global InfoBase. https://apps.who.int/infobase/mddetails aspx?surveycode=102851a1 (accessed 11 Nov 2009).

16. National behavioral risk factor survey among population aged 25-64, 2007 Bulgarian Journal of Public Health. Official Journal of The National Centre of Public Health Protection. 2009; (Supp 1):12-18

17. Health Survey 2003. Statistical Service of the Republic of Cyprus, 2005. Available from: http://www.pio.gov.cy/mof/cystat/statistics.nsf/All/ 8D77393854EAB2FBC22570070024E263/\$FILE/HEALTH SURVEY 2003.pdf? OpenElement (accessed 16 Oct 2009). Statistical Service of the Republic of Cyprus.

18. Sample survey of the health status and life style of the population in the czech republic focused on drug abuse. Riijen: Institute of Health Information and Statistics of the Czech Republic, 2006. http://www.uzis.cz/download file.php?file=2527 (accessed 12 Oct 2009).

19. National Institute of Public Health (Statens Institut for Folkesundhed) Health and Morbidity 1987-2005 (Sundheds- og sygelighedsundersogelserne 1987-2005). http://susy2.si-folkesundhed.dk/susy.aspx (accessed 16 Nov 2009).

20. Health and morbidity 2005 (Sundheds- og sygelighedsundersøge/sen 2005 Interviewskema med svarfordeling). København: Statens Institut for Folkesundhed, 
2006. http://www.si-folkesundhed.dk/upload/susy svarfordelinger 001.pdf (accessed 31 Jan 2010).

21. Ekholm 0, Kjøller M, Davidsen M, et al. Health and Morbidity in DenmarkDevelopment since 1987/Sundhed og sygelighed i Danmark \& udviklingen siden 1987). København: Statens Institut for Folkesundhed (SIF), 2006. http://www. si-folkesundhed.dk/upload/hele rapporten 2005.pdf (accessed 08 Oct 2009).

22. Tekkel M, Veideman T, Rahu M. Health Behavior among Estonian Adult Population, 2006. Tallinn: National Institute for Health Development, 2007. http://www2.tai.ee/ uuringud/TKU2006.pdf (accessed 06 Oct 2009).

23. Helakorpi S, Patja K, Prättälä $\mathrm{R}$, et al. Health behaviour and health among the Finnish adult population, Spring 2006. Helsinki: KTL-National Public Health Institute, Finland, 2007. http://www.ktl.fi/attachments/suomi/julkaisut/julkaisusarja b/2007/ 2007b01.pdf (accessed 06 Oct 2009).

24. Beck F, Guilbert P, Gautier A. Health Barometer 2005 (Baromètre santé 2005 Attitudes et comportements de santé Baromètres santé: un éclairage sur leur méthode et leur évolution). Saint-Denis Cedex France: Institut national de prévention et d'éducation pour la santé, 2007. http://www.inpes.sante.fr/Barometres/BS2005/pdf/ BS2005 Methodologie.pdf (accessed 28 0ct 2009).

25. Beck F, Guilbert P, Gautier A. Health Barometer 2005 (Baromètre santé 2005 Attitudes et comportements de santé. Les Français et la cigarette en 2005: un divorce pas encore consommé). Saint-Denis Cedex France: Institut national de prévention et d'éducation pour la santé, 2007. http://www.inpes.sante.fr/Barometres/BS2005/pdf/ BS2005 Tabac.pdf (accessed 08 0ct 2009).

26. Federal Statistical Office (Statistisches Bundesamt). Life in Germany-hauseholds, family and health: results from Mikrozensus 2005 (Leben in Deutschland-Haushalte Familien und Gesundheit: Ergebnisse des Mikrozensus 2005). Wiesbaden: 2006. http:// www.destatis.de/jetspeed/portal/cms/Sites/destatis/Internet/DE/Presse/pk/2006/ Mikrozensus/Pressebroschuere,property=file.pdf (accessed 08 0ct 2009).

27. Mikrozensuserhebung. http://www.mikrozensus.com/ (accessed 29 0ct 2009).

28. Federal Statistical Office. Mikrozensus-Fragen zur Gesundheit. http://www. destatis.de/jetspeed/portal/cms/Sites/destatis/Internet/DE/Content/Statistiken/ Gesundheit/GesundheitszustandRisiken/Content75/Gesundheitszustand Behandlungsanlaesse,property=file.pdf (accessed 17 Nov 2009)

29. Vardavas CI, Kafatos AG. Smoking policy and prevalence in Greece: an overview. Eur J Public Health 2007;17:211-13.

30. European Health Interview \& Health Examination Surveys Database. https:// hishes.iph.fgov.be/index.php?hishes=his_headerghis_header_id=132\&submit_edit $=1$ \&view_mode=survey (accessed 12 Nov 2009)

31. World Health Organization Global InfoBase. https://apps.who.int/infobase/ reportviewer.aspx? rptcode $=$ ALL\&surveycode $=102320 \mathrm{a} 1 \& d \mathrm{dm}=8$ (accessed $12 \mathrm{Nov}$ 2009).

32. National Health Interview Survey 2003 executive update. Budapest: Johan Béla National Centre for Epidemiology, 2004. http://www.oszmk.hu/dokumentum/ OLEF 2003/NatHealthIntervSurvey2003.pdf (accesssed 15 Nov 2009).

33. Morgan K, McGee H, Watson D, et al. Survey of lifestyle, attitudes and nutrition in Ireland 2007-main report. Dublin: Department of Health and Children, 2008. http:// www.slan06.ie/SLAN2007MainReport.pdf (accessed 08 Oct 2009).

34. Brugha R, Tully N, Dicker P, et al. SLÁN 2007: survey of Lifestyle, attitudes and nutrition in Ireland. Smoking patterns in Ireland: implications for policy and services. Dublin: Department of Health and Children, 2009. http://intranet.rcsi.ie/slan06/ SLAN_2007_Smoking_Report.pdf (accessed 17 Nov 2009)

35. SLAN: survey of lifestyle, attitudes and nutrition. SLAN-2006 annotated questionnaire. http://www.slan06.ie/SLAN-07FinalAnnotated.pdf (accessed 17 Nov 2009)

36. National Institute of Statistics of Italy (ISTAT). Aspects of daily living (Aspetti della vita quotidiana). http://www.istat.it/strumenti/rispondenti/indagini/ famiglia_societa/vitaquotidiana/ (accessed 10 Nov 2009).

37. National Institute of Statistics of Italy (ISTAT) Everyday Life 2006(La vita quotidiana nel 2006). Roma, 2007. http://www.istat.it/dati/catalogo/20071106_00/inf0712 La vita quotidiana 2006.pdf (accessed 08 0ct 2009).

38. National Institute of Statistics of Italy (ISTAT) Everyday life 2007(La vita quotidiana nel 2007). Roma, 2008. http://www.istat.it/dati/catalogo/20090312_00/inf0810la_vita_ quotidiana ne \%202007.pdf (accessed 10 Nov 2009).

39. Pudule I, Villerusa A, Grinberga D, et al. Health behaviour among Latvian adult population, 2006. Helsinki, Finland: Public Health Agency, Latvia \& National Public Health Institute, 2007. http://www.ktl.fi/attachments/suomi/julkaisut/julkaisusarja_b/ 2007/2007b27.pdf (accessed 06 0ct 2009).

40. Grabauskas V, Klumbiene J, Petkeviciene J, et al. Health behaviour among Lithuanian adult population, 2006. Helsinki, Finland: Kaunas University of Medicine, Institute for Biomedical Research, Lithuania \& KTL-National Public Health Institute, 2007. http://www.ktl.fi/attachments/suomi/julkaisut/julkaisusarja_b/2007/2007b07. pdf (accessed 06 Oct 2009).

41. Tabagisme au Luxembourg: Bilan 2007 (Smoking in Luxembourg: Review 2007). Fondation Luxembourgeoise Contre Le Cancer, 2008. http://cancer.lu/images/ uploads/Tabac Lux cp2008 site.pdf (accessed 20 0ct 2009).

42. Lifestyle Survey 200̄7. Valetta: National Statistics Office Malta, 2009. http://www nso.gov.mt/statdoc/document file.aspx?id=2483 (accessed 20 0ct 2009).

43. Smoking prevalence 2004-2008. (Rookprevalentie 2004-2008). Den Haag: STIVORO, 2009. http://www.stivoro.nl/Upload/_publdocs/Rookprevalentie\%202004-2008.pdf (accessed 13 Nov 2009).

44. Ciecielag P, Lednicki B, Moskalewicz J, et al. Health Status of Population in Poland 2004(Stan Zdrowia Ludnosci Polski w 2004 R). Warszawa: Glowny Urzad
Statystyczny, 2006. http://www.stat.gov.pl/cps/rde/xbcr/gus/PUBL stan zdrowia 2004.pdf (accessed 20 Oct 2009)

45. National Statistical Institute of Portugal (Instituto Nacional de Estatística, IP). National Health Survey 2005/2006 (Inquérito Nacional de Saúde 2005/2006). Portugal, Lisboa: Inquérito Nacional de Saúde, 2009. http://www.insa.pt/sites/INSA Portugues/Publicacoes/Outros/Documents/Epidemiologia/INS 05 06.pdf laccessed 08 0ct 2009).

46. European Health Interview \& Health Examination Surveys Database. https:// hishes.iph.fgov.be/index.php?hishes=his questionsqhis header $\mathrm{id}=221$ \&print $=1$ \& view mode=survey (accessed 12 Nov 2009 ).

47. Centre of Health Policies and Studies (Centrul pentru Politici și Servicii de Sănătate). Knowledge, Attitudes and Practices of the General Population on the Consumption of Tobacco and the Legislative Provisions (Cunostințele, atitudinile si practicile populației generale referitoare la consumul de tutun și la prevederile legislative din domeniu) 2007. Romania: București. http://www.ms.ro/fisiere/ pagini_virtuale/284_578_StudiuCPSS_07_complet.pdf (accessed 27 0ct 2009)

48. Statistical Office of the Slovak Republic (Statistický úrad Slovenskej republiky). Prevalence of Drug Use in Slovakia, and Citizens' Views on the Problems Associated with Drug Addiction (Rozšírenosť uživania drog na Slovensku a názory občanov na problémy spojené s drogovou závislosťou) 2006. Bratislava. http://portal. statistics.sk/files/Uvvm/y2007/publikacie/electronic/110706.pdf laccessed 11 Nov 2009).

49. Institute of Public Health of the Republic of Slovenia (Inštitut za varovanje zdravja). http://www.ivz.si/index.php?akcija =novica\&n=1662 (accessed 30 0ct 2009)

50. Statistical Office of the Republic of Slovenia and the Institute of Public Health of the Republic of Slovenia. Health and health care in Slovenia. Ljubljana 2009. http://www.ivz si/javne datoteke/datoteke/1757-Health and health care in Slovenia.pdf (accessed 12 Oct 2009)

51. National Statistics Institute (Instituto Nacional de Estadisctica). National Health Survey-Methodology (Encuesta Nacional De Salud 2006/ 2007-Metodologia Detallada). http://www.ine.es/metodologia/t15/t153041906.pdf (accessed 30 0ct 2009).

52. National Statistics Institute (Instituto Nacional de Estadisctica). National Health Survey-Questionnaire for adults (Encuesta Nacional de Salud Cuestionario de Adultos). http://www.ine.es/metodologia/t15/ens adu06.pdf laccessed 30 0ct 2009).

53. National Statistics Institute (Instituto Nacional de Estadistica). National Health Survey 2006/2007 (La Encuesta Nacional de Salud Espana 2006/2007) http://www.msc.es/en/estadEstudios/estadisticas/encuestaNacional/ encuestaNac2006/EstilosVidaPorcentaje.pdf (accessed 13 Oct 2009).

54. Swedish National Institute of Public Health. http://www.fhi.se/Documents/ Statistik-uppfoljning/Folkhalsoenkaten/Resultat-2008/Tobak-tabeller-090417.xls (accessed 19 0ct 2009).

55. Swedish National Institute of Public Health. Health on equal terms? Study on health and lifestyle in Sweden 2006. (Hälsa pa lika vilkor? En undersökning om hälsa och livsvillkor i Sverige 2006). http://www.fhi.se/Documents/Statistik-uppfoljning/ Folkhalsoenkaten/Enkatformular-LISTA/Formular-nationell-2006.pdf laccessed 30 0ct 2009)

56. Statistics Sweden. Technical report. 'Hälsa på lika villkor?' Enkätundersökning 2006, Det nationella urvalet. http://www.fhi.se/Documents/Statistik-uppfoljning/ Folkhalsoenkaten/Resultat-arkiv/Tekniskrapport/Teknisk-rapport-2006.pdf laccessed 30 Oct 2009)

57. Wadman C, Boström G, Karlsson A. Health on equal terms? Results from the 2006 Swedish National Public Health Survey. Swedish National Institute of Public Health, 2008.

58. Ali R, Greer J, Matthews D, et al. General Household Survey, 2006. Sample design and response. Appendix B. Newport: Office for National Statistics, 2008. http:// www.statistics.gov.uk/Statbase/Product.asp?vlnk=5756 (accesed 30 Oct 2009)

59. Ali R, Greer J, Matthews D, et al. General Household Survey, 2006. Household and individual questionnaires. Appendix E. Newport: Office for National Statistics, 2008. http://www.statistics.gov.uk/Statbase/Product.asp?vlnk=5756 (accessed 30 0ct 2009).

60. Goddard E. General Household Survey, 2006. Smoking and drinking among adults, 2006. Newport: Office for National Statistics, 2008. http://www.statistics.gov.uk/ Statbase/Product.asp?vlnk=5756 (accessed 30 Oct 2009)

61. Population estimates-August 2009. Statistical bulletin. Office for National Statistics. http://www.statistics.gov.uk/pdfdir/pop0809.pdf laccessed 07 May 2010)

62. The ASPECT Consortium. Tobacco or health in the European Union-past, present and future. Luxembourg: ASPECT Consortium/European Commission, 2004.

63. Lifting the smokescreen-10 reasons for a smoke free Europe. 2006. The Smoke Free Partnership. http://www.ersnet.org/ers/show/default.aspx?id_attach=13509 (accessed 19 Nov 2009).

64. The health consequences of involuntary exposure to tobacco smoke: a report of the surgeon general, U.S. Department of Health and Human Services. U.S. Department of Healthy Human Services, 2006. http://www.surgeongeneral.gov/library/ secondhandsmoke/factsheets/factsheet2.html (accessed 19 Nov 2009).

65. West R, Zatonski W, Przewozniak K, et al. Can we trust national smoking prevalence figures? Discrepancies between biochemically assessed and self-reported smoking rates in three countries. Cancer Epidemiol Biomarkers Prev 2007:16:820-2. 